\title{
ÁREAS VERDES E ESPAÇO LIVRES URBANOS
}

VLADIMIR BARTALINI*

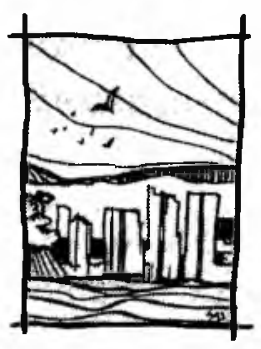

As funções que as áreas verdes e os espaços livres desempenham no meio urbano podem ser agrupadas em três conjuntos:

O primeiro diz respeito aos valores visuais ou paisagísticos,em senso estrito.

O segundo aos valores recreativos.

$\mathrm{O}$ terceiro aos valores ambientais.

Estas funções não são excludentes: um determinado espaço pode desempenhar papel relevante nas condições ambientais de uma cidade e ao mesmo tempo ter um grande potencial recreativo e ser um elemento de destaque na paisagem urbana. Seria ideal que estas funções sempre estivessem interligadas. Se as apresentamos separadamente é por conveniência de exposição e por permitirem, assim separadas, estudos mais aprofundados e intervençōes objetivas.

\section{VALORES VISUAIS (REFERENCIAIS)}

Um dos problemas mais freqüentes que podem ser detectados na paisagem urbana é o da falta, ou perda, de identidade visual. Preocupados, e com razão, com a localização das funções, estabelecimento de densidades, dimensionamento da infra-estrutura ou com a eficiência do sistema viário, os planos geralmente minimizam ou ignoram um aspecto fundamental para a qualidade de vida dos cidadãos: a criação ou valorização de referenciais urbanos, a caracterização fisionômica das cidades.

O crescimento das cidades, que leva à sua expansão sobre a área rural ou à renovação de áreas urbanas preexistentes, transforma em curto espaço de tempo a fisionomia dos lugares. A este fato se acrescenta o desenvolvimento da tecnologia que não só possibilita a alta velocidade destas transformações como também acarreta a homogeneidade das paisagens resultantes das intervenções: terrenos acidentados são facilmente aplainados, córregos sinuosos são retificados ou tampados, obstáculos são vencidos por vias elevadas, áreas rurais diversificadas se transformam em subúrbios monótonos, os testemunhos da 
natureza original e da história podem facilmente desaparecer. Muitas vezes os lugares resistem a esta tendência geral de homogeneização conservando ou criando. mesmo que precariamente, referenciais próprios que favorecem a formação de vínculos simbólicos da população com o lugar onde ela vive. Assim se dá com os pontos de encontro tradicionais, com certos sítios históricos, com uma determinada rua. ou construção, e porque não, com os elementos da paisagem natural que tão bem conseguem caracterizar uma região até pelos processos construtivos dos seus edifícios, pelo traçado das suas ruas, e mesmo pela arborização e mobiliário urbano.

Espaços livres e áreas verdes podem exercer um importante papel na identidade dos lugares, quer enfatizando as características físicas do sítio, quer atuando como limites de áreas urbanizadas, formando compartimentos de paisagem. Exemplos felizes, hoje infelizmente perdidos, da associação de características do sítio e áreas verdes formando uma imagem significativa foram o Parque Anhangabaú e o Parque D. Pedro na cidade de São Paulo, ligados respectivamente aos rios Anhangabaú e Tamanduateí. Outro exemplo, ainda válido, são as serras cobertas por vegetação na cidade do Rio, ainda suficientemente fortes para se contrapor à massa edificada. Ou também o Parque da Encosta proposto em Salvador, aproveitando o característico desnível entre cidade alta e cidade baixa.

Cursos d'água, represas, são elementos que podem ser valorizados pelas áreas verdes a eles associados e se tornarem referenciais válidos para uma cidade. Certos pontos privilegiados da topografia permitem visões panorâmicas que situam o observador no contexto geral da paisagem. Faz-se necessário o controle da ocupação do solo e a previsão de espaços livres em torno destes pontos e nos ângulos visíveis a partir deles, de modo a garantir a qualidade do cenário.

Ainda entre as funções de caráter visual destaca-se o papel das áreas verdes enquanto "amortecedores" entre massas construídas, como contraponto à geometria dos edifícios ou como plano de fundo.

O planejamento visual da paisagem envolve, portanto, a organização dos diversos elementos que a compõem buscando, na associação entre as formas produzidas pela sociedade e aquelas pertencentes à própria base física do território, a preservação ou criação de valores cênicos e de referenciais válidos para uma determinada área urbana.

\section{VALORES RECREATIVOS (UTILIZAÇĀO)}

Além do importante papel da qualidade visual da paisagem e nas condiçōes ambientais urbanas, as áreas verdes e espaços livres merecem uma atenção especial pelas funções que desempenham na recreação. 
O crescimento urbano cria uma situação contraditória no tocante às áreas verdes e espaços livres: ao mesmo tempo que a demanda por estes espaços aumenta. a sua oferta diminui. O estoque de áreas públicas para esta função pode ser pequeno ou nulo. e o preço da terra muitas vezes coloca fora de cogitação a aquisição de novas áreas ou só a possibilita em locais muito afastados, ainda de difícil acesso pela população.

Esta situação nos leva a considerar as possibilidades de aproveitamento do conjunto de espaços livres disponíveis, públicos e privados, abrindo alternativas para suprir a carência neste setor. Além daqueles designados convencionalmente para este fim, poderão ser incluídos como espaços propícios à recreação: as ruas ociosas em termos de tráfego: lotes vagos ou áreas privadas com vegetação significativa, que apresentem interesse para concessão temporária de uso mediante os acertos legais e tributários que se fizerem necessários: áreas de feiras confinadas ou de estacionamento de veículos que possam vir a ter um uso múltiplo em dias e horários alternados. etc.

Seria muito conveniente que todo o patrimônio ambiental, urbano ou rural, estivesse vinculado ao sistema de áreas livres para fins recreativos e culturais. É uma forma de protegê-lo, valorizá-lo e suprir as carências do sistema.

Os espaços abertos de recreação. tanto os convencionais (praças, parques. campos de esporte...) como os que poderíamos chamar de adventícios, devem constituir um sistema que atenda às várias escalas: da vizinhança ao setor urbano, do setor urbano ao município ou à região.

Na previsão da demanda futura o aproveitamento do potencial existente pode não ser suficiente, fazendo-se necessária a aquisição ou reserva de novas áreas. $\mathrm{O}$ critério de aquisição, baseado na maior superfície pelo menor preço não satisfaz plenamente. Será necessário considerar: a localização (um terreno menor, a maior preço, pode ser vantajoso devido à sua importância estratégica), as funções que se desenvolvem no seu entorno, a sua acessibilidade física e visual. Neste sentido é interessante observar que, salvo uma razão mais forte do ponto de vista ambiental ou fisiográfico, os espaços de caráter linear têm vantagem sobre os de superfícies extensas. Isto porque, para uma mesma superfície, aqueles apresentam, proporcionalmente, maior perímetro de contato com o tecido urbano.

Outro aspecto importante a considerar no referente aos espaços abertos de recreação é o da definição de uso e programação de atividades. $O$ descuido deste aspecto pode resultar em usos inadequados ou mesmo em ausência de uso. transformando os espaços abertos em áreas ociosas. problemáticas. É o que 
normalmente se constata nos bairros dormitórios ou em setores urbanos muito especializados ou de baixa densidade demográfica. Assim, a distribuição espacial, dimensionamento e equipamentos das áreas de recreação deverão se fazer não só por critérios demográficos e no atendimento às diversas escalas, mas também pela consideração das peculiaridades sociais, econômicas e culturais dos usuários, levando à satisfação de diferentes necessidades.

\section{VALORES AMBIENTAIS}

As áreas verdes podem influir na qualidade ambiental urbana e exercer papel importante na proteção do meio ambiente.

O efeito mais sensível da vegetação sobre as condições ambientais é o de amenizador da temperatura: a sensação de conforto térmico proporcionada pela arborização urbana é uma experiência que está no repertório do cidadão comum, sobretudo nos climas tropicais e equatoriais. No entanto. o papel da arborização urbana vai além desta sensação tátil imediata. Sendo a temperatura das áreas cobertas por vegetação sensivelmente menor que a das áreas nuas ou edificadas, produzem-se variações térmicas que podem contribuir na ventilação da cidade. Assim a arborização urbana pode atenuar os efeitos das "ilhas de calor" que tendem a se formar sobre as cidades, influindo. portanto, na temperatura, nos ventos e na pluviosidade, ou seja, nas condiçōes climáticas.

Já no controle do ruído urbano a vegetação não apresenta a mesma eficiência. Medições científicas têm comprovado que seriam necessárias grandes extensōes de barreira vegetal para um abatimento significativo no nível de ruídos. No entanto, associada a variações de topografia, aproveitando-se ou criando-se desníveis entre a fonte emissora e o receptor, a vegetação pode vir a ter uma eficiência razoável na atenuação do ruído regular do tráfego, com uma barreira da ordem de $6 \mathrm{~m}$ de largura.

Ainda é insuficiente o conhecimento do papel da vegetação na redução da poluição do ar.

Sabe-se, com certeza, que ela sofre os seus efeitos e disto é prova suficiente o caso da Serra do Mar junto ao complexo industrial de Cubatão em São Paulo. Tem-se verificado, também, que há espécies mais resistentes que outras às condições adversas do ar. Isto não nos anima porque só vem confirmar a vegetação como paciente da poluição. Mas, se por um lado a vegetação tem uma ação limitada como absorvedora dos poluentes, por outro ela pode ter um papel 
importante na dispersão do ar poluído, através da formação de correntes de ventilação. Verificou-se também a eficiência da vegetação na retenção da poeira.

Outro papel ativo da vegetação está na proteção do solo. Nas áreas urbanas este efeito é particularmente importante nas áreas de encostas íngremes sujeitas à erosão. Os episódios trágicos de deslizamento de morros. com enormes prejuízos à população, podem ser evitados se a estas áreas sensíveis estiverem associadas áreas verdes de proteção.

Ao defender o solo contra a erosão, as áreas verdes estão ao mesmo tempo garantindo boas condições para o armazenamento de água no subsolo, protegendo os mananciais, o que talvez possa parecer uma preocupação deslocada do contexto das regiões florestadas com alto índice de pluviosidade. No entanto, vale sempre lembrar a capacidade nada desprezível da urbanização de transformar o ambiente natural, podendo levar ao colapso o abastecimento de água. que já é uma ameaça muito próxima às nossas maiores cidades e cuja solução, muitas vezes, acaba se dando às expensas de cidades menores.

Ao proteger os cursos d'água, as margens de represas e as cachoeiras, as áreas verdes estão também protegendo um valioso patrimônio paisagístico e recreativo.

\section{CONSIDERAÇŌES FINAIS}

Vimos assim que, embora tratadas separadamente segundo a predominância dos valores visuais. recreativos ou ambientais, as funções das áreas verdes se imbricam. Um parque de vizinhança é sobretudo uma área de recreação, mas pode vir a ser também um importante elo de um sistema que assegure boas condições ambientais ao meio urbano. A arborização dos passeios é sem dúvida um amenizador climático, porém se as intenções param ali, e não se consideram seus atributos plásticos, a paisagem urbana fica prejudicada. Da mesma forma grandes extensões de áreas verdes de interesse ambiental, mas sem qualquer possibilidade de uso por mais restrito que seja, ou ainda sem acessibilidade visual, dificilmente ganharão um significado coletivo e estarão assim mais facilmente expostas às pressões especulativas.

$\mathrm{Na}$ formação de um sistema de áreas verdes, as várias funções devem ser consideradas nas suas inter-relações. Os critérios meramente quantitativos não satisfazem. O que significam 10.20 ou 30 metros quadrados de área verde por habitante? É necessário saber para que servem, onde se localizam, como estão distribuídos. 
Também não se mostraram eficientes os modelos de distribuição homogênea. $O$ urbano é sobretudo heterogêneo. Um sistema de áreas verdes não é um sistema independente que se superpõe ao urbano: deve estar intimamente associado a ele.

A política de um sistema de áreas verdes também não pode se limitar à aquisição ou reserva de grandes áreas nas periferias das cidades. Pode ser um procedimento louvável, sobretudo se se tratar de áreas onde a proteção de certos processos naturais se faz necessária. Mas é também necessário considerar alternativas para suprir carências e melhorar as condições ambientais nos locais onde há maior concentração populacional e, portanto, grande demanda de uso.

As propostas que levem em conta a variedade e simultaneidade de funções que as áreas verdes podem desempenhar, que procurem entender as características físicas do sítio urbano. os processos naturais que nele atuam. que considerem as tendências dos processos sociais que movem a cidade e que sejam sensíveis às necessidades e aos valores culturais da população, são as que têm maiores possibilidades de oferecer melhores condições à paisagem e ao ambiente urbano.

Ainda é necessário acrescentar que a sustentação de um plano depende não só da vontade política por parte do poder público. mas da identidade que a população possa estabelecer entre seus objetivos e os do plano.

Isto é verdade não só para a implantação do plano, mas sobretudo no que diz respeito ao uso e à manutenção.

Por fim, um bom plano, na escala macro, não garante por si só um bom resultado. É necessário que as várias escalas do plano sejam tratadas criteriosamente. Muitas vezes um desenho inadequado pode propiciar um uso inadequado e acabar destruindo valores que o plano visava preservar. Outras vezes a escolha imprópria dos materiais ou das espécies vegetais pode comprometer os resultados esperados. Um bom desempenho não significa o uso de formas prolixas, nem o uso de materiais sofisticados, mas sempre leva em conta a adequação ao meio (em sentido amplo) e aos usuários.

Texto originalmente publicado no Paisagem e Ambiente - Ensaios II.

(*) Arquiteto e mestre pela FAUUSP, professor e pesquisador da FAUUSP e PUCCAMP. doutorando FAUUSP. 